Original Research Paper

\title{
The Effect of Therapeutic Group Therapy to Mother's Knowledge about Cognitive and Psychosocial of Preschool-age Children
}

\author{
Shinta Dewi Kasih Bratha, Meri Neherta and Dewi Eka Putri \\ Faculty of Nursing, Andalas University, Limau Manis Padang. Indonesia
}

\author{
Article history \\ Received: 22-05-2018 \\ Revised: 29-06-2018 \\ Accepted: 10-07-2018 \\ Corresponding Author: \\ Shinta Dewi Kasih Bratha \\ Faculty of Nursing, Andalas \\ University, Limau Manis \\ Padang. Indonesia \\ Email: shintadkb@qmail.com
}

\begin{abstract}
A non-optimal growth might affect the mental development of children. Mental development disorder's children around the world were classified as high. To prevent that situation it was required a consant stimulation from the mother. Providing stimulation was supported by mother's knowledge about children growth and development so that stimulation could be given according to the growth stage. Therapeutic group therapy was one of the altematives that provide knowledge to the mother in doing a developmental stimulation according to the children's age. The purpose of this research was to determine the effect of therapeutic group therapy on rnother's knowledge in providing a cognitive and psychosocial developmental stimulation of preschool-age children. This research used "Quasi-experiment pre-post test control group" with therapeutic Group Therapy intervention of preschool-age children (3-4 years). The result of this research obtained that the cognitive aspect of mother's knowledge was 0,070 ( $p$ value $>0,05$ ) which implied that there was no difference between intervention and control group. Whereas in the psychosocial aspect it was found that knowledge of mother was 0,460 (p value $>0,05)$ which meant that there was no difference between intervention and control group. With the providing of this therapy, it was expected to improve the development of preschoolers. especially on the cognitive and psychosocial aspects.
\end{abstract}

Keywords: Therapeutic Group Therapy, Mother's Knowledge, Developmental Stimulation

\section{Introduction}

Preschoolers (3-6 years old) is a critical period that has a profound effect concerning the success of the growth and development process that must be accomplished by adults (Shoshani et al., 2017). This growth can be observed in seven aspects; motoric, cognitive, language, emotional, personality, religious and moral character as well as psychosocial. Cognitive development during preschoolers plays an important role because children will be able to evaluate the consequence of an event or age-related change in mental activities (Hapsari, 2016). According to Erikson, psychosocial development during preschoolers is better known as initiative versus guilt. Initiatives are used to possess and pursue various goals and also to suppress or delay a goal. Objectives that must be restrained will bring about a sense of guilt or sin (Xing et al., 2017). This psychosocial aspect will influence other aspects of development in children. The process of development that is not working optimally will lead to disturbance and affect the mental development of children. Mental development disorders among children around the world classified as high, such as in the United States reaching $12-16 \%$, Thailand 24\%, Argentina $22 \%$ and Indonesia $13-18 \%$. The prevalence of children's mental development disorder in Indonesia tends to increase in the last 6 years (Cameron et al., 2017).

Non-optimal development can lead to mental health problems. Some cases of psychiatric problems occur due to the lack of attention and stimulation of the parents that are given during childhood. In China, it is recorded that $75 \%$ of the perpetrators of violent acts in adulthood is caused by the lack of parents' attention during their childhood (Balseviciene et al., 2014). Meanwhile, many teenagers in Australia do criminal acts, free sex and become bullies at their school (Mills et al., 2013). In the United States, it is reported that there are around $13-20 \%$ 
children with mental health problems during 1994-2011 and countries in Asia have $10-20 \%$ of children and adolescents who have experienced mental health problems (Nikolaev et al., 2016). The high number of mental health disorders within preschoolers can be handled by increasing the stimulation of growth and development in children (Years, 2014). In Indonesia, out of 1000 children aged 4-15 years, 140 children experience mental and emotional problems (Riskesdas, 2013).

Prevention efforts of mental health problems can be done by stimulating the growth and development of healthy children, so it can maintain the mental health status of the child (Years, 2014). A mother must be able to provide stimulus for her children and the most efficient is at the age of 24-48 months (Kim et al., 2017). According to Hurlock, at the age of 3 to 4 years, physical maturity occurs in the brain and the nervous system that can improve motoric skills. If the maturity of the brain is accompanied by appropriate stimulation, it will produce optimal development of the child (Kim et al., 2017). The stimulation presentation should be supported by mother's knowledge about child growth so that the stimulation can be given accordance with the stage of development (Conference and Psychology, 2012). According to Murphy (2017), the process of giving this stimulation can also not be arbitrary because only four kinds of stimuli that will be saved by the child, those are the first being recorded, the more reliable, more enjoyable and that lasted continuously.

Based on the results of Feil's research (2017) in America, obtained that $75 \%$ of mothers have no knowledge about children development in accordance with their age. Mothers are not able to provide appropriate stimulation with aspects of child development. So that, the child development is handed over thoroughly to school or another educational place (Feil et al., 2017). Stimulation is also obtained from Early Childhood Education and Development (ECED) which is presented by teachers, but it is limited due to the unbalanced number of teachers and children. Therefore, it should be extended by a continual stimulation of the mother at home (Cameron et al., 2017). The problem that is still encountered by the mother in providing development stimulus is that the mother provides excessive stimulation only on the elements of cognitive development so that she does not allow the children to play outside the home (Spielfogel et al., 2011).

To overcome this circumstance, it is required the role of nurses who can help mothers in implementing knowledge to stimulate children for their optimal development. Nursing services in the form of Community of Mental Health Nursing (CMHN) that should exist in the Public Health Center (Puskesmas) are demanded to provide knowledge to the mother in stimulating child development (Damayanti, 2010). Nurses as a part of the health services need to implement a community-based mental health care approach that not only focuses on mental disorders but also to improve the quality of life of healthy communities (Years, 2014). The services of psychiatric nursing can be provided in the form of intervention and therapy for individuals, families and groups. A variety of therapies can be given by the nurses such as family therapy, supportive and therapeutic group therapy.

Therapeutic group therapy is an alternative in this situation. Therapeutic group therapy is a promotive action to enhance child development to be optimal so as to limit the appearance of mental health problems (Nugter and Engelsbel, 2015). Therapeutic group therapy is applied to a proper group which is suitable for the development of age to increase the potential for gaining an optimal growth.

Therapeutic group therapy of preschoolers consists of five sessions which are the evaluation of preschoolers development and stimulation of fine and gross motor, the stimulation of cognitive and language development, the stimulation of emotional and personality development, the stimulation of moral, religious and psychosocial development and the evaluation of child development. Therapeutic group therapy can educate and improve the potential of members and improve the quality of the group in handling problems both individually and in groups (Enns et al., 2016).

Meanwhile, in Indonesia, Istiana (2015) has done a therapeutic group therapy toward school-age children which has an impact on the mental development of these children. Therapeutic group therapy also gives an influence on the mental development of adolescents as has been done by Maryatun (2014) in Banjarmasin. From all the research about therapeutic group therapy conducted in Indonesia, researchers assume that this is the best alternative to observe mother's knowledge in stimulating cognitive development and psychosocial within preschoolers.

The efforts to improve the quality and develop the potencies of children, in line with the establishment of Padang Panjang City, West Sumatra which began to concentrate on nurturing the younger generation. Early childhood education in Padang Panjang City is the primary alternative for parents in nurturing preschoolers. However, the stimulation is not optimal for each child because the children presence is only around 3-4 hours a day and the number of teachers that are disproportionate to the number of pupils. This inspired the researchers to conduct a research to provide therapeutic group therapy regarding mother's knowledge and ability about the mental development of preschoolers in Padang Panjang City. The purpose of this research was to determine the effect of therapeutic group therapy regarding mother's knowledge in providing stimulation of cognitive and psychosocial development of preschoolers. 


\section{Method}

\section{Research Design}

Quasi-experimental pre-post test control group was used as a research design with an intervention of Therapeutic Group Therapy on preschoolers. This research was conducted to observe the variety of mother's knowledge in giving stimulation of development within 3 to 4 year-olds children before and after therapy in Padang Panjang City.

\section{Research Sample}

Random cluster sampling was used in this research to collect samples and obtained 40 respondents for the intervention group and 40 respondents for control group with inclusion criteria: (1) Willing to be the respondent, (2) Have 3-4 years old children in Padang Panjang City (3) Willing to follow therapy from beginning to end of session, (4) Able to read-write..

\section{Reseacrh Ethics}

Before collecting the data, researchers first followed the ethical test at the Faculty of Medicine of Andalas University Padang. Then the researchers requested written consent from the participants, including the explanation of the research and conducted a voluntary commitment from the participants. Participants had the option to accept or reject and all personal information was kept confidential. In addition, the researchers also conducted expert tests before doing the research. The researchers administered the research approval and prepared the enumerator (for data collecting) who had been willing to assist in pre and post data-collecting activities. After preparing the data collector, the researchers determined the research location in West Padang Panjang as the control group and East Padang Panjang as the intervention group. One intervention group consisted of 5 respondents (mother and child). The intervention was conducted in 5 sessions in 3 meetings for duration 1 month.

\section{Results}

From the demographic data, it was found that the respondents were preschoolers in their 3 and 4 years old. In the intervention group, there were 25 children in their 3 years old and 15 children aged 4 years. Whereas, in the intervention group there were 22 children aged 3 years and 18 children aged 4 years. There were 22 girls and 18 boys in the intervention group. While in the control group, there was 19 girls and 21 boys. In the intervention group, there were 26 mothers who did not work and 14 mothers who were working. Meanwhile, in the control group, there were 17 mothers who did not work and 23 mothers were working. Based on statistical results, both groups were homogeneous.

Table 1 represents mothers' knowledge in providing stimulation of cognitive and psychosocial development of preschoolers before therapy in intervention and control groups. Based on the table, it was obtained that the average of mothers' knowledge about cognitive aspect in the intervention group was 2,68 and 3,15 in the control group. Based on the result of the statistical test of cognitive aspect obtained $p$-value $<0,05$ which meant there was a difference of mothers' knowledge in intervention and control group. If we observed from the psychosocial aspects, it was found that the average knowledge of mothers in the intervention group was 4.30 and 5.78 in the control group. Based on the result of the statistical test, mother's knowledge in psychosocial aspect was found that $p$-value $<0,05$ so that there was no difference between intervention and control group.

Table 2 illustrates the analysis of mothers' knowledge before and after therapeutic group therapy in the intervention group. It was obtained a score of $0.051 \mathrm{p}$ value $>0.05$ ) which meant that there were no differences in the cognitive aspects before and after therapy. Whereas in psychosocial aspect, obtained a score of 0,027 ( $p$-value $<0,05$ ) which meant there was a significant difference in mothers' knowledge within the intervention group before and after therapy. While the analysis of mothers' knowledge before and after therapy in the control group, obtained that mothers' knowledge on cognitive aspect was 0,183 ( $p$ value $>0,05$ ) which meant that there was no difference between before and after. In the psychosocial aspect, mothers' knowledge in control group was 0.323 ( $\mathrm{p}$ value $>0,05$ ) which meant that there was no difference before and after.

Table 3 shows mother's knowledge of cognitive aspect in giving stimulation after therapeutic group therapy. Obtained a score of 0,070 ( $p$ value $>0,05)$ which meant that there was no difference between intervention and control group. Whereas in the psychosocial aspect, it was found that mothers' knowledge was 0,460 ( $\mathrm{p}$ value $>$ 0,05 ) which meant that there was no difference between intervention and control group.

Table 1: Analysis of mothers' knowledge in giving stimulation of preschoolers development before therapy on intervention and control group

\begin{tabular}{llllll}
\hline Development dimensions & Group & $\mathrm{N}$ & Mean & SD & P-Value \\
\hline Cognitive & Intervention & 40 & 2,68 & 1,207 & 0,041 \\
Psychosocial & Control & 40 & 3,15 & 0,802 & \\
& Intervention & 40 & 4,30 & 1,814 & 0,000 \\
& Control & 40 & 5,78 & 1,074 & \\
\hline
\end{tabular}


Table 2: Analysis of mothers' knowledge in giving stimulation of preschoolers development before and after therapy on intervention and control group

\begin{tabular}{lllllll}
\hline Group & Development Dimensions & Time & $\mathrm{N}$ & Mean & SD & P-Value \\
\hline Intervention & Cognitive & Before & 40 & 2,68 & 1,207 & 0,051 \\
& & After & 40 & 2,85 & 1,099 & 0,027 \\
& Psychosocial & Before & 40 & 4,30 & 1,814 & 1,707 \\
\multirow{4}{*}{ Control } & & After & 40 & 4,60 & 0,802 & 0,183 \\
& Cognitive & Before & 40 & 3,15 & 0,768 & \\
& & After & 40 & 3,22 & 1,074 & 0,323 \\
& Psychosocial & Before & 40 & 5,78 & 1,091 & \\
\hline
\end{tabular}

Table 3: Analysis of mothers' knowledge in giving stimulation of preschoolers development after therapy on intervention and control group

\begin{tabular}{llllll}
\hline Development Dimensions & Group & $\mathrm{N}$ & Mean & SD & P-Value \\
\hline Cognitive & Intervention & 40 & 2,85 & 1,099 & 0,81 \\
& Control & 40 & 3,22 & 0,768 & \\
Psychosocial & Intervention & 40 & 4,60 & 1,707 & 0,000 \\
& Control & 40 & 5,80 & 1,091 & \\
\hline
\end{tabular}

\section{Discussion}

The differences in mothers' knowledge after therapy in both intervention and control groups did not have any significant change. In the intervention group, there is an increase in mother's knowledge regarding psychosocial aspects. This occurs because, before the therapy, respondents do not know about the psychosocial aspects. Even the researchers get many questions when giving therapy in psychosocial aspects. Starting from a child's ability to help with simple homework, playing with household appliances and enjoy playing with peers with gender-based games, visiting neighbors, friends or relatives without parents, making family albums, playing creatively with friends, playing selling and shopping are the stimulation on psychosocial aspects (Hapsari, 2016). This has led to significant changes before and after treatment. Through the presenting of stimuli can support the participants during the learning process (Bhinnety, 2012). As more stimulus is given, it enhances a person in some way. The method of therapy given in this intervention is a very suitable stimulation during the adult learning process (Ur and Govt, 2016).

There is no significant difference in the cognitive aspect. This happens because some mothers brought non-preschoolers during the therapy. Consequently, the researchers unable to concentrate even though they had tried to focus on each individual. However, the characteristic of Indonesian society who have more toddlers in a family presents a particular challenge for the researchers. A noisy environmental factor can affect the outcome of the therapy because it can interrupt the absorption of information (Gwinner, 2016). An unbalanced quantity of groups might disrupt the implementation of therapy because the concentration of respondents would split (Damayanti, 2010). The researchers suggest that during this therapy, the respondents do not bring other toddlers so that they can concentrate on the therapy.

Therapeutic group therapy is a promotive action to enhance child development to be optimal so as to prevent the appearance of mental health problems. This therapy allows participants to share their experiences and help each other to solve problems, including to anticipate upcoming problems by training effective ways to control stress (Nugter and Engelsbel, 2015). Therapeutic group therapy also intends to develop the ability of members and mutually strengthening to form an adaptive behavior (Damayanti, 2010). This research also performs aforementioned. However, unlike previous therapy, the researchers only set small groups which consist of 3 to 5 people for each group. It intended to let the researchers focus on every person and surely teach all aspects for each respondent.

There was no significant change in the control group. Actually, mothers' knowledge in the control group may increase through pre-test and post-test because the questions in the tests are the evaluation that must be completed by the respondent. The questions can remind the respondents about everything they are supposed to know regarding aspects of development within preschoolers. In the learning process of an adult, people will believe in a new knowledge if they feel the necessity. Consequently, there will be a learning process that is formed by the individual itself.

The improving of mothers' knowledge in the therapy group indicates the importance of providing therapeutic therapy groups for preschoolers to enhance children development according to their age. However, in providing this therapy, the researchers should concentrate on each respondent in order to optimize the results of this research. 
In the presenting of therapeutic group therapy, it can be concluded that the improvement of mothers' knowledge can happen if there is a conducive environment, high curiosity from the respondent and active cooperation of the participants. When conducting the therapy, researchers should anticipate the surroundings and encourage the respondents about the importance of this therapy for the development of preschoolers. Thus, it can enhance the knowledge of mothers or respondents in giving development stimulation toward preschoolers, especially on cognitive and psychosocial aspects.

\section{Conclusion}

There was no change regarding mothers' knowledge in the cognitive aspect before and after therapeutic group therapy in the intervention and control group. Meanwhile, there was a meaningful change of the psychosocial aspects within the intervention group. And there were significant differences before and after therapeutic group therapy in the intervention and control group. With this therapy, it was expected to improve the development of preschoolers, especially on the cognitive and psychosocial aspects. Suggestions for next researchers, optimize the granting of therapy and suggest participants only to bring preschoolers, where a conducive environment makes participants focus on receiving therapy.

\section{Acknowledgment}

This is a non-grant sponsored research.

\section{Author's Contributions}

Shinta Dewi Kasih Bratha: Developed and finalized the manuscript.

Meri Neherta: Supervised and provided feedback for the manuscript.

Dewi Eka Putri: Supervised and provided feedback for the manuscript.

\section{Ethics}

This study has been reviewed by the ethical committee of Faculty of Medicine no 127/KEP/FK/2018 and meet all the requirements of intervention study.

\section{References}

Balseviciene, B., L. Sinkariova and S. Andrusaityte, 2014. Do Green spaces matter? The associations between parenting stress, child mental health problems and green spaces. Procedia - Social Behavioral Sci., 140: 511-516.

DOI: $10.1016 /$ j.sbspro.2014.04.462
Bhinnety, M., 2012. Struktur dan Proses Memori. Social Sci. Med., 16: 74-88.

Cameron, X.J.L., K.L. Eagleson, N.A. Fox, T.K. Hensch and X. Levitt, 2017. Social origins of developmental risk for mental and physical illness. J. Neurosci., 37: 10783-10791.

DOI: 10.1523/JNEUROSCI.1822-17.2017

Conference, I. and E. Psychology, 2012. Relationship Between Parent's Spiritual Intelligence, level of education and children's mental health, 69(Iceepsy). pp: $2114-2118$.

Damayanti, R., 2010. Pengaruh Terapi Kelompok Terapeutik terhadap Kemampuan Ibu dalam Memberikan Stimulasi Perkembangan Inisiatif Anak Usia Prasekolah di Kelurahan Kedaung Bandar Lampung 2010.

Enns, J., M. Holmqvist, P. Wener, G. Halas and A. Schultz et al., 2016. Mapping interventions that promote mental health in the General Population: A scoping review of reviews. Preventive Medicine. DOI: 10.1016/j.ypmed.2016.02.022

Feil, E.G., A. Frey, H.M. Walker, J.W. Small and J.R. Seeley et al., 2017. The efficacy of a home-school intervention for preschoolers with challenging behaviors: A randomized controlled trial of preschool first step to success. J. Early Intervention, 36: 151-170. DOI: $10.1177 / 1053815114566090$

Gwinner, K., 2016. Arts, therapy and health: Three stakeholder viewpoints related to young people's mental health and wellbeing in Australia. Arts Psychotherapy. DOI: 10.1016/j.aip.2016.05.016

Hapsari, I.I., 2016. Psikologi perkembangan anak. Indeks: Jakarta.

Istiana, D., 2015. Terapi kelompok terapeutik anak dengan orang tua dan guru meningkatkan perkembangan mental anak usia sekolah.

Kim, M.H., L. Shimomaeda, R.J. Giuliano and E.A. Skowron, 2017. Experimental child intergenerational associations in executive function between mothers and children in the context of risk. J. Experimental Child Psychology, 164: 1-15. DOI: 10.1016/j.jecp.2017.07.002

Maryatun, 2014. Pengaruh terapi kelompok terapeutik terhadap perkembangan remaja di panti sosial marsudi putra dharmapala inderalaya. J. Srivijaya Nursing, 1: 12-20.

Mills, R., J. Scott, R. Alati, M.O. Callaghan and J.M. Najman et al., 2013. Child abuse and neglect child maltreatment and adolescent mental health problems in a large birth cohort ${ }_{\text {a. }}$. Child Abuse Neglect, 37: 292-302. DOI: 10.1016/j.chiabu.2012.11.008

Nikolaev, E.L., E.A. Baranova and S.A. Petunova, 2016. Mental Health Problems in young children?: The role of mother's coping and parenting styles and characteristics of family functioning. Procedia Social Behavioral Sci., 233: 94-99.

DOI: $10.1016 /$ j.sbspro.2016.10.152 
Notoadmodjo, Soekidjo. (2012). Promosi Kesehatan dan Perilaku Kesehatan. Rineka Cipta Jakarta.

Nugter, M.A. and F. Engelsbel, 2015. Outcomes of FLEXIBLE Assertive Community Treatment (FACT) Implementation: A prospective real life study. Community Mental Health J., 52: 898-907. DOI: $10.1007 / \mathrm{s} 10597-015-9831-2$

Riskesdas, 2013. Badan Statistik Indonesia.

Shoshani, A., M. Slone and L.E. Prino, 2017. Positive education for young children: Effects of a positive psychology intervention for preschool children on subjective well being and learning behaviors. Front. Psychol., 8: 1-11. DOI: 10.3389/fpsyg.2017.01866
Spielfogel, J.E., S.J. Leathers, E. Christian and L.S. Mcmeel, 2011. Parent management training, relationships with agency staff and child mental health: Urban foster parents' perspectives. Children Youth Services Review, 33: 2366-2374. DOI: $10.1016 /$ j.childyouth.2011.08.008

Ur, A. and R. Govt, 2016. Mothers' Knowledge about Child Development.

Xing, S., X. Gao, X. Song, M. Archer and D. Zhao et al., 2017. Chinese Preschool Children's Socioemotional Development: The effects of maternal and paternal psychological control. Front. Psychol., 8: 1-9.

DOI: $10.3389 /$ fpsyg.2017.01818

Years, I., 2014. Promoting Early Childhood Mental Health. 